\title{
Competency Requirements at Digitalized Workplaces in the Semiconductor Industry
}

\author{
Sophia Keil ${ }^{1}$, Fabian Lindner ${ }^{1(\bowtie)}$, Josef Moser ${ }^{2}$, \\ Rüdiger von der Weth $^{3}$, and Germar Schneider ${ }^{4}$ \\ ${ }^{1}$ Faculty of Business Administration and Engineering, \\ Zittau/Goerlitz University of Applied Sciences, Zittau, Germany \\ \{sophia.keil, fabian.lindner\}@hszg.de \\ ${ }^{2}$ Infineon Technologies Austria AG, Villach, Austria \\ ${ }^{3}$ Faculty of Business Administration, Dresden University of Applied Sciences, \\ Dresden, Germany \\ ${ }^{4}$ Infineon Technologies Dresden GmbH \& Co. KG, Dresden, Germany
}

\begin{abstract}
Automation and digitalization in manufacturing are used as means to speed up the production, reduce its costs, and improve the quality of the products. However, new systems and technologies that are applied to achieve these goals often require great adaptation efforts by the employees using them. This is especially the case in the semiconductor industry, where there is great competitive pressure, with the need for fast, flexible and innovative manufacturing processes. This paper examines at different workplaces at Infineon Austria and Dresden, how job characteristics and required competencies have changed so far due to digitalization, and how employees can be prepared to further changes in production. Therefore, a literature review, interviews, and observations are conducted and the results presented.
\end{abstract}

Keywords: Industry $4.0 \cdot$ Competency requirements $\cdot$ Digitalized workplaces • Big data $\cdot$ Trainings $\cdot$ Education programs

\section{Introduction}

Semiconductor manufacturers face high competitive pressure regarding reduced production times, costs, and enhanced quality, as well as short innovation cycles, and the need for fast ramp-ups of new technologies (Kern 2016). The automation and digitalization of factories and manufacturing (e.g. by using handling robots), and business processes can offer opportunities to meet these challenges. Therefore, robots operating at the production line, and automated transport systems running through fabrication facilities are already widely used in the semiconductor sector. In this way, large amounts of digital information and data are generated during the whole manufacturing process, e.g. via sensors that are monitoring the machine processes and reporting on their status or specific parameters of the production to the responsible workers (Schöning and Dorchain 2014). Furthermore, information assistance systems such as head-mounted displays (HMD), that are or can be used in the production to aid the employees raise new questions about their use. Are these systems adding value to the 
supply chain by increasing the efficiency and making the work tasks more comfortable for the workers - or do they result in more distraction and strain for the colleagues? Due to this ongoing automation and digitalization employees need to cope with knowledge and competency challenges at workplaces in Industry 4.0. This notion was introduced in 2011 by the German government's high-tech strategy and essentially stands for the intelligent linkage of machines and processes using ICT. It is also seen as the next evolutionary level of fabrication (Kagermann et al. 2013).

Within the European research project iDev40 (Integrated Development 4.0) one main focus is on the role of the human within complex and highly automated and digitalized working environments. Leading questions of this part of the project are about the design of human-centered future workplaces, the efficiency of humanmachine interaction, knowledge sharing, smart collaboration, and training as well as educational programs to empower employees for Industry 4.0 scenarios.

In the following, Sect. 2 describes the research questions and the methodology used for answering them. Section 3 presents the results of the research and is divided into three subsections. The first one explains the characteristics of the three generic and production-related types of workplaces: operation, maintenance, and development workplace. The second subsection introduces relevant competencies in digitalized or Industry 4.0 working environments and compares them to the empirical findings at nowadays' workplaces in semiconductor fabrication facilities. Afterwards, measures for assessing and increasing the competency level of workers and engineers are briefly evaluated. In the end, the findings are discussed and an outlook on the topic is given.

\section{Methodology}

To contribute to the aforementioned aims of the respective iDev40 subproject, the following research questions (RQ) are proposed:

- RQ 1.1 - What characterizes automated and digitalized workplaces and work tasks in the semiconductor industry?

- RQ 1.2 - Which competency requirements must be met by employees in automated and digitalized working environments in the semiconductor industry?

- RQ 2 - How can employees in the semiconductor industry educationally and technically be empowered to meet these competency requirements?

I.e., the goal of this paper is to distinguish characteristic workplaces and to define the core competencies that workers in digitalized working environments in the semiconductor industry need. Additionally, an outlook will be given on possible (further) training opportunities. Besides studying the literature on competency requirements in Industry 4.0 and the high-tech sector in general, this paper focuses on empirical evidence. Therefore, semi-structured interviews were conducted with employees of different types of workplaces at Infineon Technologies in Villach, Austria (IFAT) on August 9th -10 th, 2018. The first part of the interview surveyed the workers' personal attitude towards and perspective on digitalization and automation at their workplace, and how it affects - or would affect - their daily working routine (Appendix A). In the second part, the employees were asked about their work with regard to the 
characteristic $5 \mathrm{~V}$ of Big Data commonly used in theory and practice: volume, variety, velocity, veracity, and value (Ilie-Zudor et al. 2015). As there is no common definition of when to speak of Big Data (Dautov and Distefano 2017), these five characteristics are mainly used to describe them. They represent challenges to the used technology, and result in "datasets that could not be perceived, acquired, managed, and processed by traditional IT and software/hardware tools within a tolerable time" (Chen et al. 2014). In this way, the interviews help to examine to which extent information and data play a role at each workplace.

In addition to the qualitative analysis of the interview transcriptions (Kuckartz 2016), the findings of several days of observation interviews (Kuhlmann 2009) of a maintenance workplace at the production site of Infineon Technologies in Dresden, Germany (IFD) between November $19^{\text {th }}$ and $23^{\text {rd }}, 2018$ are considered. The application of these mixed methods approach towards answering the before proposed research questions is depicted in Fig. 1.

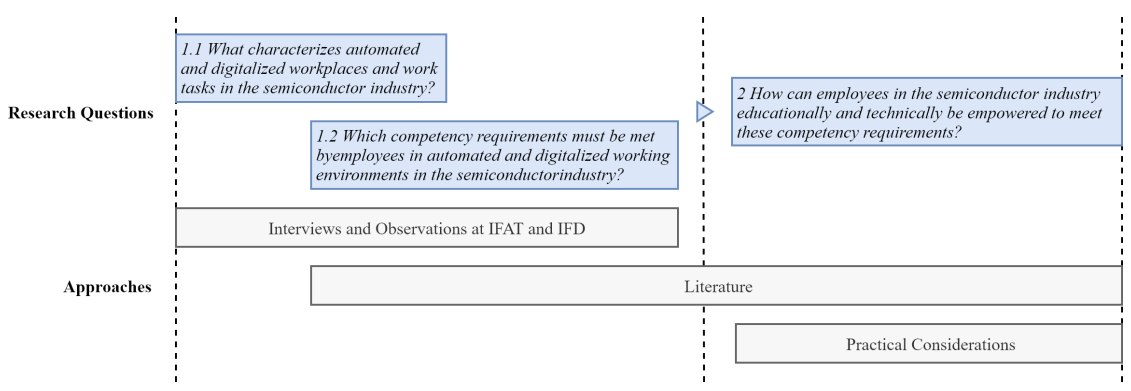

Fig. 1. Research design.

\section{Results}

\subsection{Characteristics of Digitalized Workplaces in the Semiconductor Industry}

In the beginning, three types of generic production-related workplaces at the semiconductor manufacturer Infineon Technologies are distinguished: production, maintenance, and development workplaces. The first one encompasses the workers on the shop-floor that are operating and monitoring several production machines (Fig. 2). Depending on the degree of automation on the shop floor, these employees are also more or less responsible for loading and unloading these machines, as well as fixing minor errors. Supervisors at production workplaces are furthermore accountable for procurement, prioritizing orders, organizing and leading the shift, as well as reporting to higher authorities.

Maintenance workplaces are highly characterized by monitoring, and supervision tasks, as well as repair activities - mechanically and electronically (Fig. 2). Due to the amount of IT and sensor systems that are controlling and operating the plants and the transportation systems, maintenance regarding software or sensor issues is increasing. 


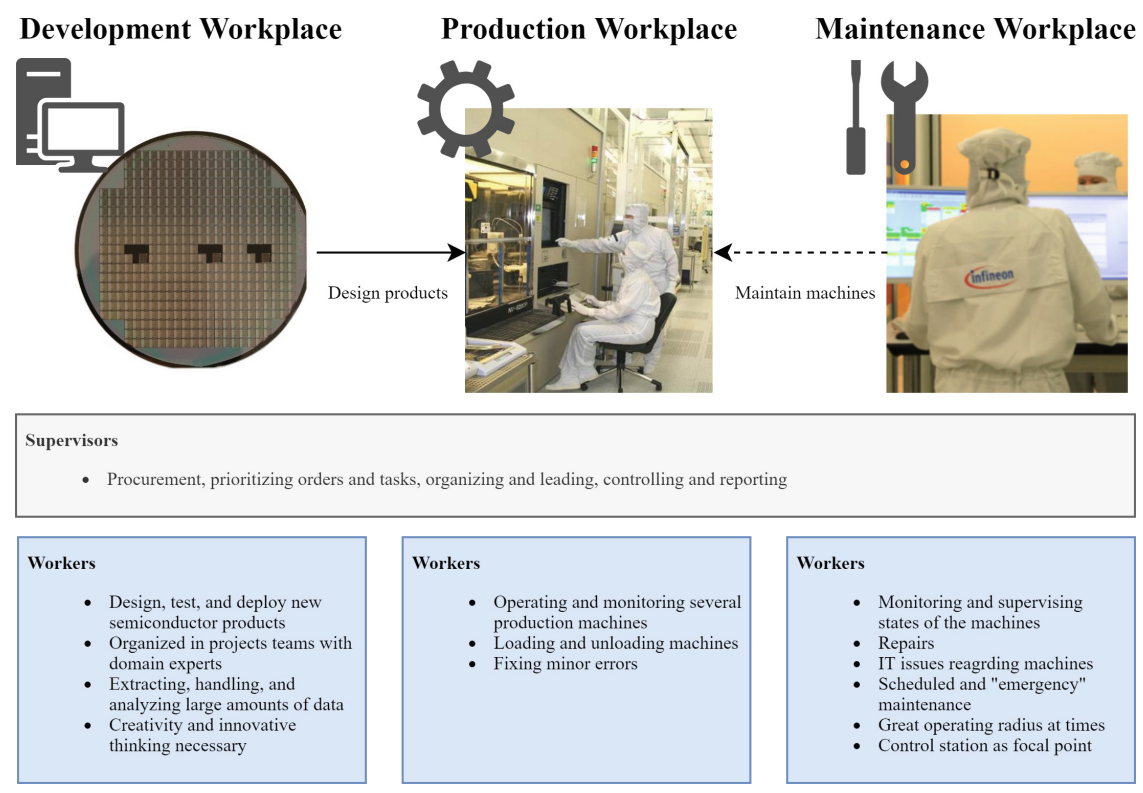

Fig. 2. Generic production and production-support workplaces at semiconductor manufacturers.

That's why part of the maintenance staff is specially trained for solving more complex IT issues as systems experts. Besides preventive maintenance activities on a regular basis before errors occur, the maintenance staff has to react quickly to unsuspected errors and fixing them to keep the production going. Different maintenance teams are responsible for different types of machines or systems. Due to this, the spatial area of action inside the fabrication facility differs as well. E.g., maintenance workers of the transportation systems are deployed all over the fabrication facility, whereas maintenance workers of a special type of machine might have a smaller operating radius - as generally similar types of machines are placed together in semiconductor fabrication facilities. When not on maintenance activities, the maintenance staff operates from within its own control room monitoring the respective systems. On supervision level, the work tasks and responsibilities are similar to those of the machine operators.

At development workplaces engineers design, test and deploy new semiconductor products in accordance with customer requests (Fig. 2). To do so, development teams are mainly organized along projects with experts for the respective tasks of the development process. At this workplace extracting, handling, and analyzing large amounts of data play an important role - electrical parameters and machine data can rise up to thousands of variables that can be examined theoretically to develop new product features or to evaluate them. Further characteristics of this workplace are the creativity and innovative thinking necessary to develop new products. However, routine tasks like data handling are still part of the job. Due to necessary expert knowledge and competencies for the development of new products these teams might be distributed over several production sites. Therefore, a successful collaboration cross-site necessitates certain communication and social skills of the employees. On the level of 


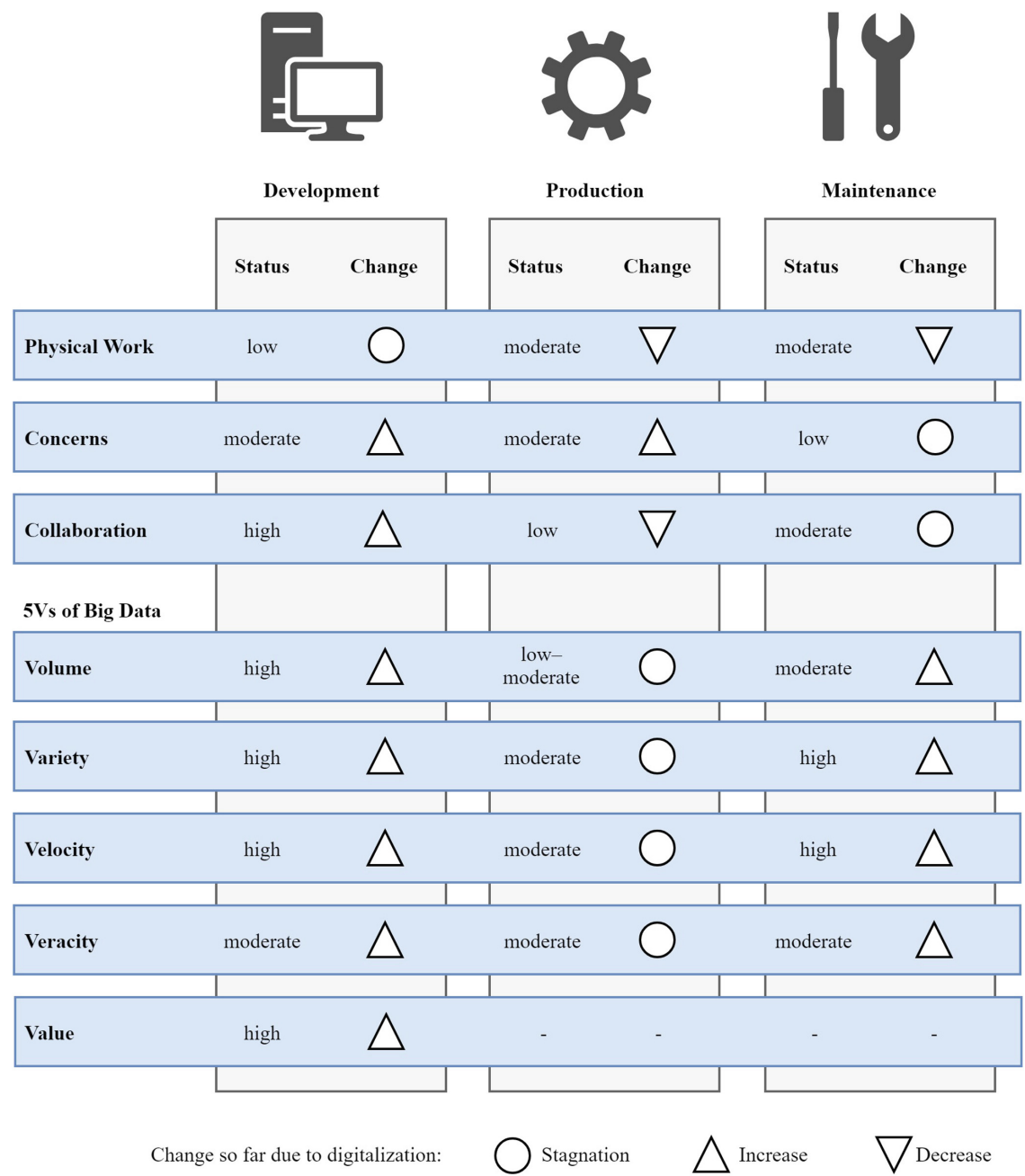

Fig. 3. Status and change of several aspects due to digitalization at the respective types of workplaces in semiconductor industry based on own findings.

supervisors, the tasks and responsibilities again do not largely differ from those at the other workplaces - at least the amount of project management and monitoring activities is increased.

On the basis of the interviews and observations several aspects with regard to digitalization can be extracted that can be used for differentiation of these three types of workplaces (Fig. 3):

- The amount of physical work and activity during the job.

- The perception of digitalization of workplaces as a risk. 
- The need for communication and collaboration.

- The 5Vs of Big Data:

- The volume of information and data that play a role at the workplaces.

- The variety of formats of information as well as the variety of sources of data.

- The velocity of generating and processing information at the workplaces.

- The veracity or quality of the information needed for the respective workflows.

- The value generated through data.

Asking the employees about their opinion of digitalization affecting their workplaces already or in the future, one of the first aspects is the amount of physical work that has to be executed. At operating and maintenance workplaces physical activities still play a role. However, digitalization (and automation) affected the work of operators the most. At maintenance workplaces the amount of physical strain in general is still high due to mechanical reparations and the greater radius of action within the fabrication facility. Whereas digitalization did not affect the work of development engineers with respect to physical tasks - it still does not play a role. Machine operators seem to see the implementation of new technologies more skeptical as e.g. maintenance workers. I.e., they might be afraid of losing their jobs due to digitalization or to be moved to a new workplace that might also require some re-training. Furthermore, the colleagues fear overstrains due to too much digital noise like unnecessary information overflows. In this context, the age distribution of the workers matters as well - older employees seem to have greater concerns as younger ones that might already be very familiar with any kinds of digital technology as they grew up in a more or less digitalized world.

Further aspects of investigation are the 5Vs of big data (Ilie-Zudor et al. 2015) to compare the three types of workplaces by characteristics of the information flows needed for planning and decision making during work. With regard to the volume of information or data that must be processed at work, developers have to cope with the most - as described before - followed by the maintenance workplaces, where machine states from different systems come together at the control station or remotely. At both workplaces the amount of data increased and is expected to increase further due to digitalization as well. At operating workplaces volume of the data, like orders, is relatively low (to moderate). In any case, the supervisors of each workplace tend to have to manage more information as the workers, as they have additional organizing tasks regarding the shift respectively the team. Considering the variety of formats and sources of data, it is a similar picture as before. Both development and maintenance workplaces get their information from several different systems or sources and in very different formats from structured to unstructured. E.g., machine data like states and advanced process control data are structured, whereas phone calls for reporting an error to the maintenance staff are unstructured. Additionally, various IT systems might exist due to different manufacturers of the plants. So far, the ongoing automation and digitalization has led to increasing variety of sources of information due to new systems e.g., that were implemented.

However, the interviewees wish further uniform and structured information flows to ease their work. Operators as well face structured and unstructured information but in a smaller scale as the others. The velocity of information is especially high at 
development and maintenance workplaces, i.e. up to real-time due to advanced process control. However, this applies not to all information flows, so that it will probably increase further. In terms of veracity of the data, at all of the workplaces the information is available in more or less good quality that is sufficient for working with it. But unstructured information like phone calls in the maintenance control station are most of the time less accurate. Due to the increase of structured data used, the veracity of the information has also increased. Value creation through extracting, examining, analyzing and searching for useful patterns in raw data in the narrow sense of the fifth $\mathrm{V}$ of big data, is solely relevant at the development workplaces, and increasing with digitalization.

However, further similarities in all workplaces with regard to digitalization exist, when asked about the overall attitude towards digitalization at work: all of them see this development as a chance - despite some concerns mentioned before. Furthermore, all of the colleagues are aware of the constant change and the required flexibility to adapt to it - either as they already made experiences with it in the past since they are working in the semiconductor industry, or as they already grew up with ever faster changes in technology. For most of them there is also a great interest in technological changes in general, and they are open-minded towards testing new technologies. Nevertheless, there is also a consensus that tasks and activities do not necessarily become easier, more comfortable or less demanding due to digitalization. The employees expect them just to change and to develop further.

Additional interesting remarks were made on possible steps for implementing new technology. It was experienced as helpful if new technologies are implemented step by step, so that everyone can gradually adapt to the changes. Furthermore, the first pilot studies with a new technology should be conducted with persons that are very enthusiastic. In this way other employees can be influenced positively in their attitude. Still, coping with new technologies or new forms of communication probably rely on some degree on personal traits, as well. Besides all technological advancements, social contact and vis-à-vis communication seem still important for the well-being of the employees. If not possible otherwise, scheduled personal meetings should be installed therefore.

\subsection{Required Competencies in Digitalized Working Environments}

As the preceding chapter has shown, the types of workplaces in the semiconductor industry differ in several analogue and digital aspects. These specifics might require different competencies of the workers as well. In the following, four different approaches of defining digital competencies are therefore presented and compared (Fig. 4). These were selected due to varying methods used for finding and extracting digital or Industry 4.0-relevant competencies, as well as varying in the scope to which they are applied to, and in the competencies itself. In this way, different approaches and perspectives are considered. In addition, the results of these studies are juxtaposed with the findings and derivations of competencies out of the analysis of the interviews and observations at Infineon Technologies (IFX). 

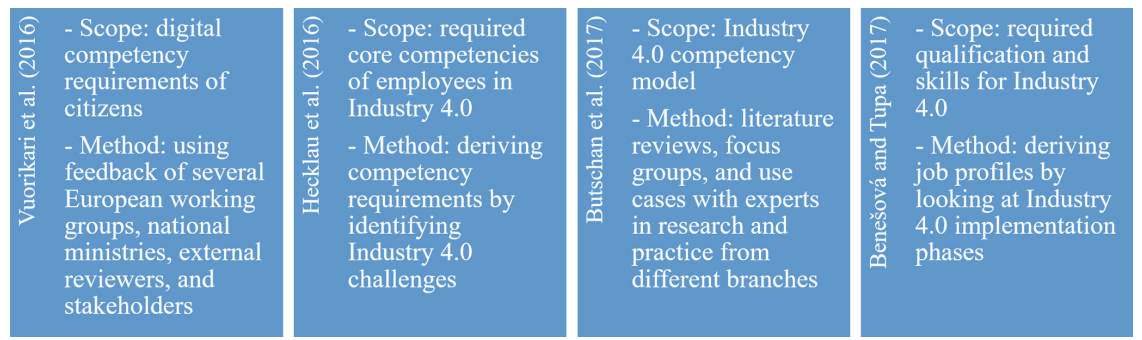

Fig. 4. Approaches of defining digital competencies.

The European Commission's in-house science service, the Joint Research Center (JRC), published in 2016 an update to the first in 2013 presented European Digital Competence Framework for Citizens (DigComp) (Vuorikari et al. 2016). Based on feedback of expert working groups from the European Commission, national ministries, external reviewers, and stakeholders, five areas of digital competencies were elaborated: information and data literacy (e.g. evaluating and managing data), communication and collaboration, digital content creation (among others: copyright and licenses, as well as programming), safety (e.g. protecting personal data and privacy or health and well-being), problem solving (creativity and identifying one's own digital competency gaps, among others).

Hecklau et al. (2016) derive four aggregated categories of required core competencies based on identified challenges arising with Industry 4.0 due to the literature: technical, methodological, social, and personal competencies. Technical competencies comprise such as state-of-the-art knowledge, media, or coding skills. Furthermore, creativity, problem, analytical, or research skills are necessary amongst other methodological competencies. The ability to transfer knowledge, leadership skills, flexibility, and the motivation to constantly learn are other social and personal competence requirements due to digitized and interconnected working environments.

Butschan et al. (2017) use a very thorough research design for developing their own Industry 4.0 competency model. They are applying mixed methods, starting with a literature review, and conducting a quantitative study as well as interviews with a focus group consisting of experts of different branches from research and practice. Finally, they are testing their findings in two use cases.

Benešová and Tupa (2017) use a different approach in presenting their findings. These authors describe necessary skills for relevant job profiles in Industry 4.0. Initially, a distinction is made between IT and production job profiles. Afterward, the job profiles of robot programmers, data analysts, or production technicians are further described in detail.

Several competencies required of workers for highly automated and digitalized working environments like Industry 4.0 are mentioned by several of these studies. Similarities and differences between these identified competencies can be seen in Table 1, where they are aggregated and subsumed under four categories for better visualization: technical, methodological, social and communication, and personal competencies. The differences between these studies are particularly noteworthy. 
E.g., solely Butschan et al. (2017) explicitly mention eagerness to experiment, and openness for change as necessary competencies for production workers to adapt to changing processes. Especially interesting is the comparison of the derived competencies of these studies with the actual observations at IFX - differentiated by the three generic types of workplaces (Table 1). Such competencies like media skills or state-ofthe-art knowledge apply to all of the workplaces, as well as the necessary openness for change to cope with the fast advances in digitalization.

Table 1. Comparison of competencies for digitalized working environments in literature and own findings - differentiated between development, production, and maintenance workplace.

\begin{tabular}{|c|c|c|c|c|c|}
\hline \multirow[t]{2}{*}{ Category } & \multirow[t]{2}{*}{ Competencies } & \multirow[t]{2}{*}{ References } & \multicolumn{3}{|c|}{$\begin{array}{l}\text { Verified by interviews } \\
\text { and observations }\end{array}$} \\
\hline & & & Dev. & Prod. & Main. \\
\hline \multirow[t]{7}{*}{$\begin{array}{l}\text { Technical } \\
\text { competencies }\end{array}$} & $\begin{array}{l}\text { State-of-the-art } \\
\text { knowledge }\end{array}$ & $\begin{array}{l}\text { Hecklau et al. (2016); } \\
\text { Butschan et al. (2017) }\end{array}$ & $\mathrm{x}$ & $\mathrm{x}$ & $\mathrm{x}$ \\
\hline & Technical skills & $\begin{array}{l}\text { Hecklau et al. (2016); } \\
\text { Benešová and Tupa } \\
\text { (2017); Vuorikari et al. } \\
\text { (2016) }\end{array}$ & $\mathrm{x}$ & $\mathrm{x}$ & $\mathrm{x}$ \\
\hline & $\begin{array}{l}\text { Process } \\
\text { understanding }\end{array}$ & $\begin{array}{l}\text { Hecklau et al. (2016); } \\
\text { Benešová and Tupa } \\
\text { (2017) }\end{array}$ & $\mathrm{x}$ & $\mathrm{x}$ & $\mathrm{x}$ \\
\hline & Media skills & $\begin{array}{l}\text { Hecklau et al. (2016); } \\
\text { Benešová and Tupa } \\
\text { (2017); Vuorikari et al. } \\
\text { (2016) }\end{array}$ & $\mathrm{x}$ & $\mathrm{x}$ & $\mathrm{x}$ \\
\hline & Coding skills & $\begin{array}{l}\text { Hecklau et al. (2016); } \\
\text { Benešová and Tupa } \\
\text { (2017) }\end{array}$ & $\mathrm{x}$ & & $(\mathrm{x})$ \\
\hline & $\begin{array}{l}\text { Understanding IT } \\
\text { security }\end{array}$ & $\begin{array}{l}\text { Hecklau et al. (2016); } \\
\text { Benešová and Tupa } \\
\text { (2017); Vuorikari et al. } \\
\text { (2016) }\end{array}$ & $\mathrm{x}$ & & \\
\hline & $\begin{array}{l}\text { Multidisciplinary } \\
\text { knowledge }\end{array}$ & Butschan et al. (2017) & $\mathrm{x}$ & & $\mathrm{x}$ \\
\hline \multirow[t]{3}{*}{$\begin{array}{l}\text { Methodological } \\
\text { competencies }\end{array}$} & $\begin{array}{l}\text { Creativity and } \\
\text { innovative spirit }\end{array}$ & $\begin{array}{l}\text { Hecklau et al. (2016); } \\
\text { Benešová and Tupa } \\
\text { (2017); Butschan et al. } \\
\text { (2017); Vuorikari et al. } \\
\text { (2016) }\end{array}$ & $\mathrm{x}$ & & $\mathrm{x}$ \\
\hline & $\begin{array}{l}\text { Entrepreneurial } \\
\text { thinking }\end{array}$ & Hecklau et al. (2016) & $\mathrm{x}$ & & \\
\hline & Problem solving & $\begin{array}{l}\text { Hecklau et al. (2016); } \\
\text { Benešová and Tupa } \\
\text { (2017); Butschan et al. } \\
\text { (2017); Vuorikari et al. } \\
\text { (2016) }\end{array}$ & $\mathrm{x}$ & $\mathrm{x}$ & $\mathrm{x}$ \\
\hline
\end{tabular}


Table 1. (continued)

\begin{tabular}{|c|c|c|c|c|c|}
\hline \multirow[t]{2}{*}{ Category } & \multirow[t]{2}{*}{ Competencies } & \multirow[t]{2}{*}{ References } & \multicolumn{3}{|c|}{$\begin{array}{l}\text { Verified by interviews } \\
\text { and observations }\end{array}$} \\
\hline & & & Dev. & Prod. & Main. \\
\hline & Conflict solving & Hecklau et al. (2016) & $(\mathrm{S})$ & & \\
\hline & Decision making & Hecklau et al. (2016) & $\mathrm{x}$ & $(\mathrm{S})$ & $\mathrm{x}$ \\
\hline & Analytical skills & $\begin{array}{l}\text { Hecklau et al. (2016); } \\
\text { Benešová and Tupa } \\
\text { (2017); Vuorikari et al. } \\
\text { (2016) }\end{array}$ & $\mathrm{x}$ & & $\mathrm{x}$ \\
\hline & Statistical skills & $\begin{array}{l}\text { Benešová and Tupa } \\
\text { (2017) }\end{array}$ & $\mathrm{x}$ & & \\
\hline & Research skills & Hecklau et al. (2016) & $\mathrm{x}$ & & $\mathrm{x}$ \\
\hline & $\begin{array}{l}\text { Efficiency } \\
\text { orientation }\end{array}$ & Hecklau et al. (2016) & $\mathrm{x}$ & $\mathrm{x}$ & $\mathrm{x}$ \\
\hline & $\begin{array}{l}\text { Organizational } \\
\text { skills }\end{array}$ & $\begin{array}{l}\text { Benešová and Tupa } \\
\text { (2017); Butschan et al. } \\
\text { (2017) }\end{array}$ & $\mathrm{x}$ & $(\mathrm{S})$ & $\mathrm{x}$ \\
\hline & $\begin{array}{l}\text { Conceptual } \\
\text { strength }\end{array}$ & Butschan et al. (2017) & $\mathrm{x}$ & & \\
\hline \multirow{8}{*}{$\begin{array}{l}\text { Social and } \\
\text { communication } \\
\text { competencies }\end{array}$} & Intercultural skills & Hecklau et al. (2016) & $\mathrm{x}$ & (x) & (x) \\
\hline & Language skills & $\begin{array}{l}\text { Hecklau et al. (2016); } \\
\text { Benešová and Tupa } \\
(2017)\end{array}$ & $\mathrm{x}$ & (x) & (x) \\
\hline & $\begin{array}{l}\text { Communication } \\
\text { skills and } \\
\text { dialogue } \\
\text { capability }\end{array}$ & $\begin{array}{l}\text { Hecklau et al. (2016); } \\
\text { Benešová and Tupa } \\
\text { (2017); Butschan et al. } \\
\text { (2017); Vuorikari et al. } \\
\text { (2016) }\end{array}$ & $\mathrm{x}$ & & $\mathrm{x}$ \\
\hline & $\begin{array}{l}\text { Networking skills } \\
\text { and relationship } \\
\text { management }\end{array}$ & $\begin{array}{l}\text { Hecklau et al. (2016); } \\
\text { Butschan et al. (2017) }\end{array}$ & $\mathrm{x}$ & & $\mathrm{x}$ \\
\hline & $\begin{array}{l}\text { Ability to work in } \\
\text { a team }\end{array}$ & $\begin{array}{l}\text { Hecklau et al. (2016); } \\
\text { Vuorikari et al. (2016) }\end{array}$ & $\mathrm{x}$ & & $\mathrm{x}$ \\
\hline & $\begin{array}{l}\text { Ability to be } \\
\text { compromising } \\
\text { and cooperative }\end{array}$ & $\begin{array}{l}\text { Hecklau et al. (2016); } \\
\text { Benešová and Tupa } \\
\text { (2017); Butschan et al. } \\
\text { (2017) }\end{array}$ & $\mathrm{x}$ & & \\
\hline & $\begin{array}{l}\text { Ability to transfer } \\
\text { knowledge and to } \\
\text { teach }\end{array}$ & $\begin{array}{l}\text { Hecklau et al. (2016); } \\
\text { Butschan et al. (2017) }\end{array}$ & $\mathrm{x}$ & $\mathrm{x}$ & $\mathrm{x}$ \\
\hline & $\begin{array}{l}\text { Leadership skills } \\
\text { (staff } \\
\text { development } \\
\text { incl.) }\end{array}$ & $\begin{array}{l}\text { Hecklau et al. (2016); } \\
\text { Benešová and Tupa } \\
\text { (2017); Butschan et al. } \\
\text { (2017) }\end{array}$ & (S) & (S) & (S) \\
\hline
\end{tabular}


Table 1. (continued)

\begin{tabular}{|c|c|c|c|c|c|}
\hline \multirow[t]{2}{*}{ Category } & \multirow[t]{2}{*}{ Competencies } & \multirow[t]{2}{*}{ References } & \multicolumn{3}{|c|}{$\begin{array}{l}\text { Verified by interviews } \\
\text { and observations }\end{array}$} \\
\hline & & & Dev. & Prod. & Main. \\
\hline & Responsibility & $\begin{array}{l}\text { Benešová and Tupa } \\
\text { (2017) }\end{array}$ & $\mathrm{x}$ & $\mathrm{x}$ & $\mathrm{x}$ \\
\hline & Reliability & $\begin{array}{l}\text { Benešová and Tupa } \\
\text { (2017) }\end{array}$ & $\mathrm{x}$ & $\mathrm{x}$ & $\mathrm{x}$ \\
\hline \multirow[t]{11}{*}{$\begin{array}{l}\text { Personal } \\
\text { competencies }\end{array}$} & $\begin{array}{l}\text { Eagerness to } \\
\text { experiment }\end{array}$ & Butschan et al. (2017) & $\mathrm{x}$ & & (x) \\
\hline & $\begin{array}{l}\text { Flexibility and } \\
\text { mobility }\end{array}$ & $\begin{array}{l}\text { Hecklau et al. (2016); } \\
\text { Benešová and Tupa } \\
\text { (2017); Butschan et al. } \\
\text { (2017) }\end{array}$ & $\mathrm{x}$ & & $\mathrm{x}$ \\
\hline & $\begin{array}{l}\text { Openness for } \\
\text { change and } \\
\text { adaptability }\end{array}$ & Butschan et al. (2017) & $\mathrm{x}$ & $\mathrm{x}$ & $\mathrm{x}$ \\
\hline & Holistic thinking & Butschan et al. (2017) & $\mathrm{x}$ & & \\
\hline & Initiative & Butschan et al. (2017) & & & (x) \\
\hline & Autonomy & $\begin{array}{l}\text { Benešová and Tupa } \\
\text { (2017) }\end{array}$ & & & \\
\hline & $\begin{array}{l}\text { Ambiguity } \\
\text { tolerance }\end{array}$ & Hecklau et al. (2016) & $\mathrm{x}$ & & \\
\hline & $\begin{array}{l}\text { Motivation to } \\
\text { learn }\end{array}$ & $\begin{array}{l}\text { Hecklau et al. (2016); } \\
\text { Benešová and Tupa } \\
\text { (2017); Butschan et al. } \\
(2017)\end{array}$ & $\mathrm{x}$ & $\mathrm{x}$ & $\mathrm{x}$ \\
\hline & $\begin{array}{l}\text { Ability to work } \\
\text { under pressure }\end{array}$ & Hecklau et al. (2016) & & $\mathrm{x}$ & $\mathrm{x}$ \\
\hline & $\begin{array}{l}\text { Sustainable } \\
\text { mindset }\end{array}$ & $\begin{array}{l}\text { Hecklau et al. (2016); } \\
\text { Vuorikari et al. (2016) }\end{array}$ & $\mathrm{x}$ & $\mathrm{x}$ & $\mathrm{x}$ \\
\hline & Compliance & Hecklau et al. (2016) & $\mathrm{x}$ & & \\
\hline
\end{tabular}

$\mathrm{x}=$ match,$(\mathrm{x})=$ partially match,$(\mathrm{S})=$ match on supervisor level

Whereas, conflict solving competencies with customers were not directly observed, but might be necessary foremost at development supervisor levels. Furthermore, coding skills were only relevant for developers for sure, and partially for maintenance workers that deal with IT issues. Also worth mentioning is taking the initiative as part of required personnel competencies (Benešová and Tupa 2017). This was also observed e.g. at IFD, but the initiative proposals of the workers for improvement were or could 
not always be acknowledged by the higher instances. A sustainable mindset - including considerations of health and environmental issues (Vuorikari et al. 2016) - were foremost observed at those workplaces, where the physical amount of work is higher, i.e. at production and maintenance workplaces (Fig. 3). The workers at these workplaces showed some concerns towards worsening their health by the application of digital technology.

Matching the experienced competency requirements at the respective workplaces with those mostly general formulated ones in literature, shows that not all of the types of workplaces necessitate all of the competencies - or at least in different gradations. All in all, the comparison of these workplaces show that the production workers seem to need fewer competencies as the maintenance staff and the developers, where almost all of the identified competencies were as well observed. However, these findings underlie the restriction that not having competencies observed or derived does not mean that they were not necessary. Furthermore, the extent to which certain competencies are required might depend on the level of automation of the fab and the used technologies as well.

For a more thorough examination of the required competencies, systematically assessing those using measurements is obligatory. Therefore, in the following section different means of assessing competencies are evaluated. In addition, the comparison of competencies in literature and as observed, point at the issue of clearly separating qualifications and competencies from one another. Qualifications foremost stand for the ability to act and react in routine work tasks. And competencies represent the ability to be empowered to confidently react to unknown issues as well, and to apply and transfer them in new situations in work (Sauter and Staudt 2016b). Furthermore, personality traits do not necessarily correspond to competence patterns. But in times of digitalization and ever faster innovation cycles of new technologies especially these competencies are of relevance to empower the employees for an effective adaption.

\subsection{Measuring Digital Competency Gaps and Deriving Actions to Close Them}

Methods for Competency Measurement. For thoroughly assessing competencies of the employees there exist several approaches in literature and practice, especially in human resource management, which are shortly presented in the following. The main goal of competency measures is to depict the current state of the competency of an employee, and to compare it with the desired one. This can happen for finding a suitable candidate for a job offering or for training employees for new tasks. For visualization of the results usually a radar chart is used. From a practitioners' point of view special interest lies on the practicability of the different methods in terms of necessary effort for applying them. Therefore, Table 2 presents different approaches ordered by the expected expenditure and complexity. More complex tools are assessment centers, whereas less complex ones are e.g. test procedures or selfassessments. However, the expected expenditure does not necessarily allow any conclusions to be drawn about the success of the methods in measuring competencies. 
Table 2. Methods for competency measurement and relative complexity.

\begin{tabular}{|c|c|c|}
\hline Method & Exemplary references & Complexity \\
\hline Assessment Center (AC) & $\begin{array}{l}\text { Sauter and Staudt (2016b); Eck et al. } \\
\text { (2016) }\end{array}$ & \\
\hline $\begin{array}{l}\text { Biographical Methods } \\
\text { - Certificates } \\
\text { - Standardized Questionnaires } \\
\text { - Standardized Interviews } \\
\text { - Competency Biography } \\
\text { (Erpenbeck and Heyse) } \\
\text { - Competency Balance } \\
\text { (Psychological Models) }\end{array}$ & Sauter and Staudt (2016b) & \\
\hline Work Samples & Sauter and Staudt (2016b) & \\
\hline Activity Analysis & $\begin{array}{l}\text { Sauter and Staudt (2016b); } \\
\text { Beuscher-Mackay et al. (2009) }\end{array}$ & \\
\hline Interviews & Sauter and Staudt (2016b) & \\
\hline $\begin{array}{l}\text { Personality Models } \\
\text { - E.g. "Big Five" }\end{array}$ & Sauter and Staudt (2016b) & \\
\hline Computer Aided Simulations & $\begin{array}{l}\text { Sauter and Staudt (2016b); Sauter and } \\
\text { Staudt (Sauter et al. 2016a) }\end{array}$ & \\
\hline External Assessment & $\begin{array}{l}\text { Sauter and Staudt (2016b); Rietiker } \\
(2010)\end{array}$ & \\
\hline Self-Assessment & $\begin{array}{l}\text { Sauter and Staudt (2016b); Hillebrand } \\
\text { (2018) }\end{array}$ & \\
\hline Test Procedures & Sauter and Staudt (2016b) & \\
\hline
\end{tabular}

After having identified potential competency gaps of people for certain Industry 4.0 or workplace requirements, the next question is how to raise these competencies effectively.

Training and Educational Approaches. Choosing the suitable educational and training methods for empowering and developing the competencies of the employees, different factors have to be considered. E.g., do the measures address employees or maybe trainees or future employees? Or how effective, complex, and time-consuming are they for the wished purposes? Besides classical pedagogical concepts for increasing competencies in digital transformation, training the workers by means of digital technologies becomes more important. Here, two suitable possibilities for this purpose are briefly mentioned: project-based learning (PBL) scenarios and learning factories.

PBL scenarios are characterized by five aspects (Krajcik and Blumenfeld 2006):

1. As starting point there is a practical problem to be solved,

2. students explore the problem on their own and learn important skills,

3. students and teachers work together to solve the problem, 
4. students use (learning) technologies to give them knowledge beyond their current abilities, and

5. students develop products that solve the problem.

In accordance with this approach, Spitzer and Ebner (2017) for example applied CAD tools, 3D printing, and smart glasses to successfully teach students the usage of these tools and devices without prior knowledge. In addition, the students showed high motivation during the project.

For further hands-on education and training learning factories (Schallock et al. 2018) get more attention, as they allow the immediate application and visualization of digital technologies, as well as its use and possible issues. Abele et al. (2015) present a morphology of different types of learning factories that may vary in seven categories, such as operating model, purpose and targets, process, setting, product, didactics, and learning factory metrics. Concerning didactics, there are variabilities with respect to the learning targets (cognitive, affective, psycho-motorical), type of learning environment (greenfield, brownfield), role of trainer (instruction, demonstration, closed scenario, open scenario), evaluation, communication (onsite, remote), and others. This illustrates, that there are already plenty of possibilities that could be adapted to develop suitable environments for certain Industry 4.0 requirements.

\section{Discussion and Implications of the Findings}

The paper shows that the three generic types of workplace in semiconductor production - development, production, and maintenance workplace - differ in work- and information-related aspects like the necessary amount of collaboration, or the variety of sources of information needed for planning and decision making at work. Furthermore, digitalization so far has impacted the workplaces regarding these factors differently. The explorative interviews and observations allow as well to draw preliminary conclusions and make new hypotheses for further investigation and validation, e.g.:

- When are the workers used to new technologies (time of adaption), and when might new technologies be perceived as a burden?

- Does introducing new technologies and systems automatically mean extra effort by the workers that will only be reduced after they have adapted to it?

- How can information assistance systems help to enhance the human capabilities such as creativity at work and to eliminate frustrating factors?

A distinction seems to be possible between job specific activities that are contributing to the well-being and motivation of the workers, and those activities that are rather annoying and frustrating. Therefore, the focus of digitalization should be on processes and activities to eliminate those uncomfortable elements of the workflow, and not to extinct those that are perceived as motivating by the employees. Moreover, the personal traits of the employees seem to be an important factor for the adaption to new technologies.

As the employees are aware of the rapidly changing working environment due to digitalization, it is plausible that they are more open-minded towards ongoing training 
- as they see the need for it. In designing appropriate training and education programs to enhance workers' digital competencies, a distinction should be made between people that are already working, and those that are still in vocational training or higher education. Hence, competencies must be made measurable to identify competency gaps and the need for action for individual employees, firstly. Therefore, several methods of assessing competencies have been presented by differentiating them in terms of effort in practice. The comparison of existing competency models with the observations at the workplaces in the semiconductor industry so far have shown that there are similarities, but differences as well. And again, not all of the literature-based competencies for Industry 4.0 are relevant to all of the workplaces, or at least in different forms.

Afterward, further education programs in-house and university courses aligned with these changing job profiles due to digitalization can be developed to close the identified competency gaps. Future academic teaching might also make use of digital technologies and integrate them into the curriculum. E.g., some new course formats that combine digital and analog teaching and learning aspects proved to lead to better results of the students (Handke 2018). Especially the results regarding 5V of Big Data can be used to conceptualize information assistance systems to support the workers in their activities, and to evaluate where such systems would make sense - and where they would not. Example cases of testing innovative assistance systems are the use of Google Glasses or gesture recognition in the quality assurance of BMW (QZ-onlinde.de 2014; QZ-online. de 2015). Nonetheless, a critical view of such digital assistance systems is mandatory to avoid digitization for its own sake. They should enhance workers' skills at reasonable costs for the company without overstraining its employees.

For further validation of the results of this paper, further observations and interviews at the aforementioned three types of workplaces will be conducted at semiconductor manufacturers at different maturity levels of digitalization. In addition, a digitalization lab at the Zittau/Goerlitz University of Applied Sciences will be installed to test implementing Industry 4.0 technologies in hands-on higher education and training programs.

Acknowledgement. The project iDev40 has received funding from the ECSEL Joint Undertaking under grant agreement No. 783163. The JU receives support from the European Union's Horizon 2020 research and innovation programme. It is co-funded by the consortium members, grants from Austria, Germany, Belgium, Italy, Spain and Romania. It is coordinated by Infineon Technologies Austria AG.

\section{Appendix A}

iDev40 - Interview

August 9, 2018, Villach

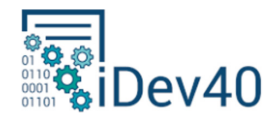




\section{Preamble:}

Within our work package 4 of the project "iDev40" we are concerned, among other things, with finding design solutions to develop the workplace of the future. To do this, it is important that we take personal assessments of the employees, to get to know how to proceed in a sensible way. For this purpose, we would like to know your opinion about the impact of digitisation on your work. At this basis, we can design digitisation solutions in such way that they are useful for your work.

\section{Procedure and questions:}

\section{$\underline{\text { Part } 1}$}

1. Thank you for your time. First, a few general questions:

2. What is your role in the company?

3. Can you briefly describe your typical tasks on a working day?

4. Does digitisation already play a role at your workplace?

5. What do you generally think of the term digitisation in the working environment?

6. In what way could digitisation be useful for your work? Can you imagine, that at certain points this means extra work for you? Do you see the topic as an opportunity or risk to your occupation?

7. How do you think digitalisation will affect your personal work in the future?

a. Are your tasks becoming simpler or more complex? (Why?)

b. Are your tasks becoming more or less interesting? (Why?)

c. Do your tasks become more comfortable or less comfortable to perform? (Why?)

d. Is more or less cooperation with colleagues necessary? (Why?)

Part 2 - Big Data

When answering the following questions, think of the most important (or most common) task you have.

\section{Volume}

8. Do you have a large amount of data and information to process?

\section{Variety = variety of data (sources, structures)}

9. Are the types of data you deal with very different?

10. How many different sources does the data come from?

11. Is the data available in raw form or does it need further processing?

\section{Velocity $=$ speed of change in data provision and data use}

12. How often do you need to retrieve this data? 


\section{Veracity $=$ are data available in the right quality, in the right place, at the right time}

13. Do you have all the information you need for your work (If "no": Which ones are missing?)

14. Are the data you use for your work available in the required quality?

(Replacement question: Is there generally information that you have to search for a long time, or that is not available so that you can deal with it?)

15. Is the data available at your workplace exactly when you need it?

16. Do you often have to involve third parties in retrieving your data?

17. Is there information that you wish you had available because then your work would be easier?

\section{Value $=$ creating value from data for companies}

18. With the things we were just talking about, can you imagine changes through digitalisation?

\section{References}

Abele, E., Metternich, J., Tisch, M., Chryssolouris, G., Sihn, W., ElMaraghy, H., et al.: Learning factories for research, education, and training. Procedia CIRP 32, 1-6 (2015). https://doi.org/ 10.1016/j.procir.2015.02.187

Benešová, A., Tupa, J.: Requirements for education and qualification of people in industry 4.0. Procedia Manufact. 11, 2195-2202 (2017). https://doi.org/10.1016/j.promfg.2017.07.366

Beuscher-Mackay, S., Jeske, T., Steiger, P., Hinrichsen, S., Schlick, C.M.: Tätigkeitsanalyse und Personalentwicklungskonzepte. In: Michael Schenk, C.M.S. (ed.) Industrielle Dienstleistungen und Internationalisierung: One-Stop Services als erfolgreiches Konzept, pp. 219-265, Gabler, Wiesbaden (2009). https://doi.org/10.1007/978-3-8349-8794-5_12

Butschan, J., Nestle, V., Munck, J.C., Gleich, R.: Kompetenzaufbau zur Umsetzung von Industrie 4.0 in der Produktion. In: Mischa, S., Lars, G., Sebastian, B. (eds.) Betriebswirtschaftliche Aspekte von Industrie 4.0, pp. 75-110. Springer Fachmedien Wiesbaden, Wiesbaden (2017). https://doi.org/10.1007/978-3-658-18488-9_4

Chen, M., Mao, S., Liu, Y.: Big data: a survey. Mob. Netw. Appl. 19(2), 171-209 (2014). https:// doi.org/10.1007/s11036-013-0489-0

Dautov, R., Distefano, S.: Quantifying volume, velocity, and variety to support (big) dataintensive application development. In: Jian-Yun, N., Zoran, O., Toyotaro, S., Rumi, G., Raghunath, N., Chonggang, W. (eds.) 2017 Proceedings of IEEE International Conference on Big Data, Boston, Piscataway, 11-14 December 2017, pp. 2843-2852. IEEE (2017)

Eck, C.D., Jöri, H., Vogt, M.: Das Assessment-Center-Verfahren und seine Durchführung. In: Claus, D.E., Hans, J., Marlène, V. (eds.) Assessment-Center: Entwicklung und Anwendung mit 57 AC-Aufgaben und Checklisten, pp. 41-112. Springer, Heidelberg (2016). https://doi. org/10.1007/978-3-662-47742-7_2

Handke, J.: Digitale Hochschullehre - Vom einfachen Integrationsmodell zur Künstlichen Intelligenz. In: Dittler, U., Kreidl, C. (eds.) Hochschule der Zukunft, pp. 249-263. Springer Fachmedien Wiesbaden, Wiesbaden (2018) 
Hecklau, F., Galeitzke, M., Flachs, S., Kohl, H.: Holistic approach for human resource management in industry 4.0. Procedia CIRP 54, 1-6 (2016). https://doi.org/10.1016/j.procir. 2016.05.102

Hillebrand, A.: Studie 2 - Fragebogenstudie. In: Ariane, H. (ed.) Welche Kompetenzen zeichnen einen Experten aus? Entwicklung eines expertenspezifischen Kompetenzmodells in einem produzierenden Unternehmen, pp. 109-223. Springer Fachmedien Wiesbaden, Wiesbaden (2018). https://doi.org/10.1007/978-3-658-22546-9_4

iDev40: Project Work. Work Plan (2019). http://www.idev40.eu/project-work/work-plan. Accessed 1 July 2019

Ilie-Zudor, E., Ekárt, A., Kemeny, Z., Buckingham, C., Welch, P., Monostori, L.: Advanced predictive-analysis-based decision support for collaborative logistics networks. Supp. Chain Manag. 20(4), 369-388 (2015). https://doi.org/10.1108/SCM-10-2014-0323

Kagermann, H., Wahlster, W., Helbig, J.: Recommendations for implementing the strategic initiative INDUSTRIE 4.0. Final Report of the Industrie 4.0 Working Group. Securing the future of German manufacturing industry (2013)

Kern, E.-M.: Verteilte Produktentwicklung. In: Lindemann, U. (ed.) Handbuch Produktentwicklung, pp. 455-481. Hanser, München (2016)

Krajcik, J.S., Blumenfeld, P.C.: Project-based learning. In: Keith Sawyer, R., (ed.) The Cambridge Handbook of the Learning Sciences, pp. 317-333. Cambridge University Press, Cambridge, New York (2006)

Kuckartz, U.: Qualitative Inhaltsanalyse. Methoden, Praxis, Computerunterstützung. 3., überarbeitete Auflage. Weinheim, Basel: Beltz Juventa (Grundlagentexte Methoden) (2016). http:// www.beltz.de/de/nc/verlagsgruppe-beltz/gesamtprogramm.html?isbn=978-3-7799-3344-1

Martin, K.: Beobachtungsinterview. In: Kühl, S. (ed.) Handbuch Methoden der Organisationsforschung. Quantitative und qualitative Methoden. 1. Aufl. Wiesbaden: Verl. für Sozialwiss./ GWV Fachverl, pp. 78-99 (2009)

QZ-onlinde.de (ed.): Qualitätskontrolle per Geste (2014). https://www.qZ-online.de/news/ uebersicht/artikel/industrie-4-0-qualitaetskontrolle-per-geste-873180.html. 21 Sept 2018

QZ-online.de (ed.): BMW. Qualitätssicherung mit Google-Brille (2015). https://www.qZ-online. de/news/uebersicht/nachrichten/bmw-qualitaetssicherung-mit-google-brille-976281.html. 21 Sept 2018

Rietiker, J.: Auswahl von Personal. In: Werkmann-Karcher, B., Rietiker, J. (eds.) Angewandte Psychologie für das Human Resource Management: Konzepte und Instrumente für ein wirkungsvolles Personalmanagement, pp. 215-237. Springer, Heidelberg (2010). https://doi. org/10.1007/978-3-642-12481-5_11

Sauter, W., Staudt, A.-K.: Kompetenzmessung in der Praxis. In: Sauter, W., Staudt, A.-K. (eds.) Kompetenzmessung in der Praxis. Mitarbeiterpotenziale erfassen und analysieren, pp. 33-44. Springer Fachmedien Wiesbaden, Wiesbaden (2016a). https://doi.org/10.1007/978-3-65811904-1_4

Sauter, W., Staudt, A.-K.: Methoden der Kompetenzmessung. In: Sauter, W., Staudt, A.-K. (eds.) Kompetenzmessung in der Praxis. Mitarbeiterpotenziale erfassen und analysieren. 1. Aufl. 2016, pp. 7-21. Springer Gabler (essentials), Wiesbaden (2016b)

Schallock, B., Rybski, C., Jochem, R., Kohl, H.: Learning factory for industry 4.0 to provide future skills beyond technical training. Procedia Manuf. 23, 27-32 (2018). https://doi.org/10. 1016/j.promfg.2018.03.156

Schöning, H., Dorchain, M.: Data mining und analyse. In: Thomas, B., ten Hompel, M., VogelHeuser, B. (eds.) Industrie 4.0 in Produktion, Automatisierung und Logistik. Anwendung, Technologien, Migration, pp. 543-554. Springer Fachmedien Wiesbaden, Wiesbaden (2014) 
Spitzer, M., Ebner, M.: Project based learning. From the idea to a finished LEGO ${ }^{\circledR}$ technic artifact, assembled by using smart glasses. In: Proceedings of EdMedia, World Conference on Educational Media and Technology 2017, Association for the Advancement of Computing in Education (AACE), pp. 196-209 (2017)

Vuorikari, R., Punie, Y., Carretero, S., van den Brande, L.: DigComp 2.0. The digital competence framework for citizens. update phase 1: the conceptual reference model. EUR 27948 EN. Publication Office of the European Union, Luxembourg (2016)

Open Access This chapter is licensed under the terms of the Creative Commons Attribution 4.0 International License (http://creativecommons.org/licenses/by/4.0/), which permits use, sharing, adaptation, distribution and reproduction in any medium or format, as long as you give appropriate credit to the original author(s) and the source, provide a link to the Creative Commons license and indicate if changes were made.

The images or other third party material in this chapter are included in the chapter's Creative Commons license, unless indicated otherwise in a credit line to the material. If material is not included in the chapter's Creative Commons license and your intended use is not permitted by statutory regulation or exceeds the permitted use, you will need to obtain permission directly from the copyright holder.

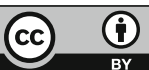

